\title{
The effect povidone-iodine on the wound healing process: A study on fibroblast populated collagen lattice (FPCL) model
}

\author{
Retno Danarti' ${ }^{1}$, Suswardana ${ }^{2}$, Arief Budiyanto' ${ }^{1}$, Widodo Wirohadidjojo ${ }^{1}$ \\ ${ }^{1}$ Department of Dermatology and Venereology, Faculty of Medicine, Universitas Gadjah \\ Mada, Yogyakarta, Indonesia. ${ }^{2}$ dr. mintohardjo Navy Hospital, Jakarta
}

\begin{abstract}
Povidone-iodine (PI) 10\% solution is an effective antiseptic. However, it appears to be toxic to the cells involved in wound healing. The aim of this study is to evaluate the toxicity of PI on cultured human fibroblast using fibroblast populated collagen lattice (FPCL) model. The cultured human fibroblast was divided into 6 groups i.e. 5 groups were exposed by PI 1, 0.1, $0.01,0.001$ and $0.0001 \%$, and 1 group was exposed by phosphate-buffered-saline (PBS). Twenty-four hours later, the media was washed using PBS. The size of the FPCL media on each group was observed over time by serial photographs, which then were measured by Image-J computer program. Exposure of $0.1,0.01,0.001$ and $0.0001 \mathrm{PI}$ caused an obvious reduction of fibroblast's contraction capability on FPCL media, which described temporary fibroblast injury, that showing a concentration-dependent recovery phenomenon after $48^{\text {th }}$ hour. Furthermore, $1 \% \mathrm{PI}$ exposure leads to a permanent fibroblast injury. In conclusion, PI exposure in concentration more than $0.1 \%$ has a permanent toxic effect on fibroblast that clearly observed using a simple $\mathrm{FPCL}$ model.
\end{abstract}

\section{ABSTRAK}

Larutan povidon iodida $10 \%$ adalah suatu antiseptik yang efektif. Namun demikian, larutan ini kemungkinan toksik terhadap sel yang terlibat dalam proses penyembuhan luka. Penelitian ini bertujuan untuk mengkaji toksisitas $\mathrm{PI}$ pada kultur fibroblas manusia menggunakan model fibroblast populated collagen lattice (FPCL). Kulture fibroblas manusia dibagi menjadi 6 kelompok yaitu 5 kelompok dipapar dengan larutan $1 ; 0,1 ; 0,01 ; 0,001$; dan 0,0001\% PI dan 1 kelompok dipapar dengan salin dapar fosfat (PBS). Dua puluh empat jam kemudian, media dicuci dengan larutan PBS. Ukuran media FPCL pada masing-masing kelompok diamati dari waktu ke waktu dengan fotograf secara serial untuk kemudian diukur dengan program komputer Image-J. Paparan PI 0,1;0,01;0,001 dan 0,0001 menyebabkan penurunan nyata kemampuan kontraksi fibroblas pada media FPCL yang menggambarkan kerusakan fibroblas sementara. Kerusakan ini menunjukkan fenomena perbaikan yang tergantung konsentrasi setelah jam ke 48 . Selanjutnya, paparan PI $1 \%$ menyebabkan kerusakan fibroblas secara permanen. Dapat disimpulkan, paparan PI pada konsentrasi lebih dari $0,1 \%$ menyebabkan efek toksik permanen pada fibroblas yang jelas teramati dengan model FPCL sederhana.

Keywords : fibroblast - povidone-iodine - toxicity - wound-healing - fibroblast injury

\footnotetext{
* corresponding author: danarti@ugm.ac.id or retnodanarti@gmail.com
} 


\section{INTRODUCTION}

Infection can slow down the wound-healing process. However, the infection can be effectively prevented using an antiseptics. Povidone-iodine (PI) is the most effective antiseptic to prevent infection. It has been widely used on $10 \%$ concentration. ${ }^{1,2}$ However, either in vivo or in vitro studies indicated that the PI, in $10 \%$ concentration, is toxic to fibroblast. ${ }^{3-6}$

Fibroblast plays an important role on all phases of wound healing. Fibroblast plays either in inflammation, proliferation, re-epithelization or remodelling phase. ${ }^{7}$ However, it is mainly responsible for collagen deposition. ${ }^{8}$ Fibroblast availability can be measured in vitro by observing its function in making a contraction on a media. ${ }^{9}$

Fibroblast Populated Collagen Lattice Contraction (FPCL) media is a model that can be used to measure fibroblast contraction. Using this model, fibroblasts are 3-dimensionly arranged in collagen matrix and will contract all the way together with collagen fibres. Fibroblastic processes that include cellproliferation, cell-to-cell contact and new collagen synthesis cause the contraction on FPCL media. ${ }^{10,11}$ The decreasing size of FPCL media is a result of fibroblasts contraction activities. Therefore, it could represent fibroblast availability. ${ }^{9,12}$

Fibroblast Populated Collagen Lattice Contraction model has not been used for fibroblastic process measurement of PI-exposed fibroblast. We determined to study the capability of fibroblast to do extra-cellular matrix reorganization by periodical observation on collagen lattice area exposed by various PI concentrations.

\section{MATERIALS AND METHODS}

It was an experimental, parallelcomparative, placebo (medium) controlled study. The study used cultured-fibroblast taken from healthy human skin and then cultivated in Dulbecco's Modified Eagle's Medium(DMEM) containing $10 \%$ fetal bovine serum, $0.1 \%$ fungizone and $0.2 \%$ gentamicin. After divided into 6 groups, the cultured-fibroblast was taken into a 36 micro-well plate. Five groups were exposed by 1, 0.1, 0.01, 0.001 and $0.0001 \%$ PI for 24 hours, whereas 1 group was exposed with phosphate-buffered saline (PBS). Povidone-iodine used was taken from Betadineâ solution (Beta Mahakam, Indonesia), which was diluted, by PBS. After 24 hours of PI exposure, the media was washed using PBS. The size of the FPCL media on each group, as a representation of fibroblast contraction capability, was observed over time on $24^{\text {th }}, 48^{\text {th }}$, $72^{\text {nd }}$ and $96^{\text {th }}$ hour time point by serial photographs which then were measured by Image-J computer program as shown in FIGURE 1.

Kruskal-Wallis and Mann Whitney post hoc test were used to analyze the difference of lattice-contraction area between PI-exposed and non PI-exposed fibroblast culture area, while Friedman and Wilcoxon rank post hoc test were used to analyze lattice-contraction area difference observed on $24^{\text {th }}, 48^{\text {th }}, 72^{\text {nd }}, 96^{\text {th }}$-hour and control group. All statistical analysis was conducted using SPSS-12 on significance level of $0.05(\mathrm{p}<0.05)$. 
Danarti et al., The effect povidone-iodine on the wound healing process: A study on fibroblast populated collagen lattice (FPCL) model

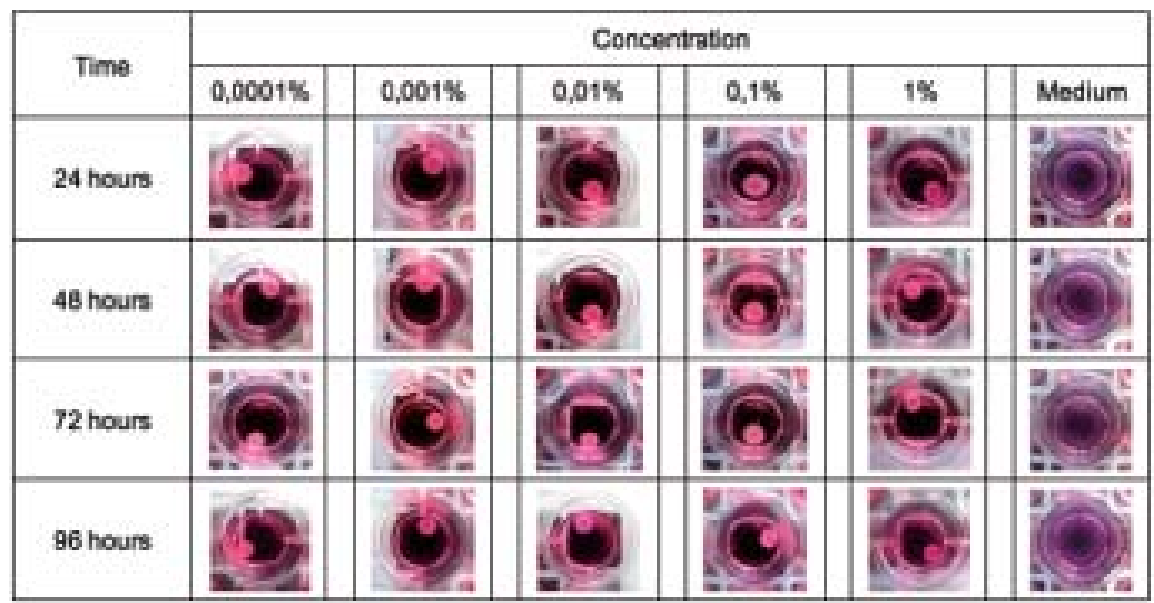

FIGURE 1. Contraction of lattice after 24, 48, 72, 96 hours exposure with PI

\section{RESULTS}

No significant difference was observed between lattice-contraction area of control group observed on $24^{\text {th }}, 48^{\text {th }}, 72^{\text {nd }}$ and $96^{\text {th }}$-hour after exposure with PI (Friedman test $\mathrm{p}=0.112$; Wilcoxon rank post hoc test $\mathrm{p}=0.180$ between all observed time). The results of Kruskal-
Wallis test of lattice contraction area (mean contraction area percentage between $0^{\mathrm{hr}}$ and on each observed time- $24^{\text {th }}, 48^{\text {th }}, 72^{\text {nd }}$ and $96^{\text {th }}$ hour) are presented on FIGURE 2, while p value of its post hoc test (Mann-Whitney test) results are presented on TABLE 1.

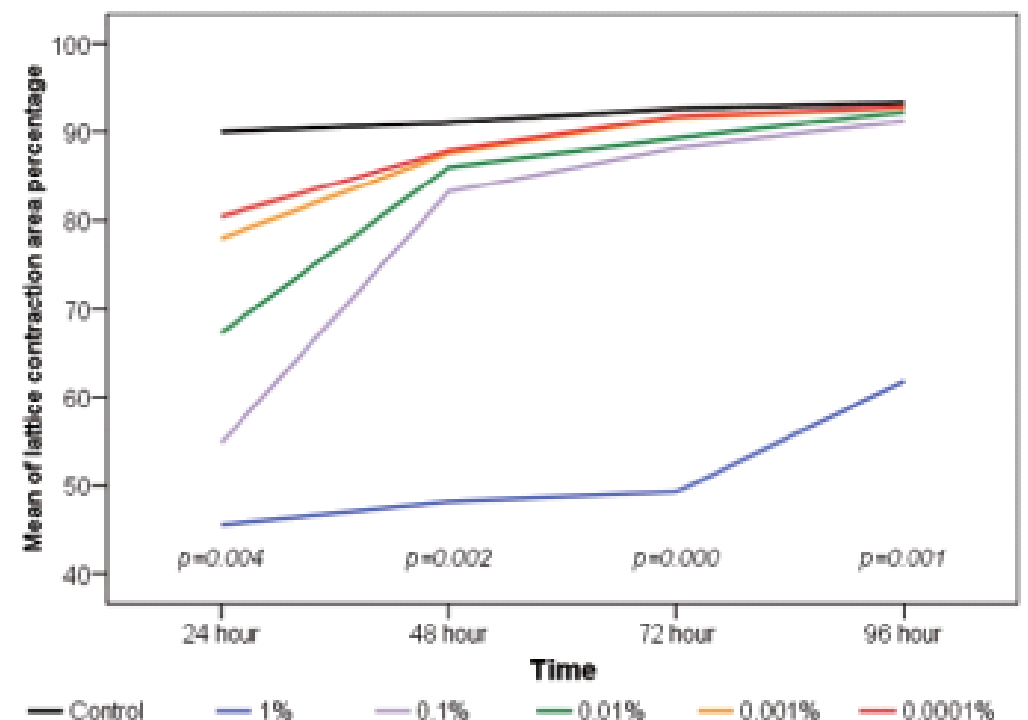

FIGURE 2. Mean of lattice contraction area percentage 
TABLE 1. Post hoc test result (p value) of treatment group compared to control group

\begin{tabular}{ccccc}
\hline \multirow{2}{*}{$\begin{array}{c}\text { PI concentration } \\
(\%)\end{array}$} & \multicolumn{4}{c}{ Duration of PI exposure (hours) } \\
\cline { 2 - 5 } & 24 & 48 & 72 & 96 \\
\hline 1 & 0.046 & 0.046 & 0.046 & 0.046 \\
0.1 & 0.046 & 0.046 & 0.046 & 0.046 \\
0.01 & 0.046 & 0.046 & 0.046 & 0.182 \\
0.001 & 0.046 & 0.046 & 0.096 & 0.505 \\
0.0001 & 0.046 & 0.096 & 0.505 & 0.505 \\
\hline
\end{tabular}

\section{DISCUSSION}

Povidone-iodine is a potent antiseptic, which widely used in $10 \%$ concentration. However, the use of PI as a toner, irrigator or wet dressing solution on an open wound is still a controversy. ${ }^{5}$ In vitro study indicates that $10 \%$ PI was toxic to cells which play an important role in wound healing process such as keratinocytes and fibroblasts. ${ }^{6}$ This study observed the effect of various PI concentrations on human fibroblasts growth using FPCL media model. Using this model, fibroblast contraction on lattice media has been optimal after 24 hour; no more significant fibroblasts contraction difference between control group and $48^{\text {th }}, 72^{\text {nd }}$, or $96^{\text {th }}$ groups $(\mathrm{p}=0.112)$.

Based on FIGURE 1 and TABLE 1, the study indicated that exposure to 0.1, 0.01, 0.001 and $0.0001 \mathrm{PI}$ for 24 hours caused a temporary cells injury on fibroblast, which showing a recovery phenomenon after 48th hour. Therefore, the lattice contraction area of each treatment group has a similar size with the control group, after 96 hours observation. Over time observation showed that recovery phenomenon found in this study was a concentration dependent; therefore that the higher PI concentration exposed to fibroblasts, the longer time needed for a fibroblast recovery. This finding is in accordance with previous studies on fibroblast and polymorphonuclear (PMN) lymphocytes cells. ${ }^{4,13}$
However, cells injury caused by 1\% PI exposure in our study did not showed recovery phenomenon which could be a sign of fibroblast toxicity. Previous studies reported that PI in 10\% concentration, ${ }^{6} 2 \%$ concentration, ${ }^{14} 1 \%$ concentration, ${ }^{4}$ or even in $0.5 \%$ concentration, ${ }^{15}$ has a cytotoxic effect on fibroblast, polymorphonuclear cells and osteoblast. These findings were in accordance with our result, but using various PI low concentrations in our method, we could report that the safe PI concentration on fibroblast was less than $0.1 \%$ concentration. Moreover, compared to other complicated methods used in observing fibroblast cells injury/toxicity, ${ }^{4,13-15}$ our study could show the toxicity of various PI concentrations on fibroblast using simple FPCL media as a model.

\section{CONCLUSIONS}

Povidone-iodine exposure in concentration more than $0.1 \%$ has a permanent toxic effect on fibroblast. Moreover, this phenomenon could be clearly observed using a simple FPCL model.

\section{ACKNOWLEDGEMENTS}

We want to thank Mrs Tari Turner from Monash University, Australia who kindly improved the style of this manuscript. 


\section{REFERENCES}

1. Mayer DA. Povidone-iodine and wound healing: A critical review. Wounds 1993; 5:14-23.

2. Burks RI. Povidone-iodine solution in wound treatment. Phys Ther 1998; 78(2):212-8.

3. Lineaweaver W, Howard R, Soucy D, McMorris S, Freeman J, Crain C, et al. Topical antimicrobial toxicity. Arch Surg 1985; 120(3):267-70.

4. Balin AK, Pratt L. Dilute povidone-iodine solutions inhibit human skin fibroblast growth. Dermatol Surg 2002; 28(3):210-4.

5. Karukonda SR, Flynn TC, Boh EE, McBurney EI, Russo GG, Millikan LE. The effects of drugs on wound healing: part II. Specific classes of drugs and their effect on healing wounds. Int J Dermatol 2000; 39(5):321-33.

6. Lineaweaver W, McMorris S, Soucy D, Howard R. Cellular and bacterial toxicities of topical antimicrobials. Plast Reconstr Surg 1985; 75(3):394-6.

7. Singer AJ, Clark RA. Cutaneous wound healing. N Engl J Med 1999; 341(10):738-46.

8. Karukonda SR, Flynn TC, Boh EE, McBurney EI, Russo GG, Millikan LE. The effects of drugs on wound healing: part I. Int J Dermatol 2000; 39(4):250-7.
9. Dallon JC, Ehrlich HP. A review of fibroblastpopulated collagen lattices. Wound Repair Regen 2008; 16(4):472-9.

10. Howling GI, Dettmar PW, Goddard PA, Hampson FC, Dornish M, Wood EJ. The effect of chitin and chitosan on fibroblast-populated collagen lattice contraction. Biotechnol Appl Biochem 2002; 36(Pt 3):247-53.

11. Ehrlich HP. The fibroblast-populated collagen lattice: A model of fibroblast collagen interactions in repair. Methods Mol Med 2003; 78:277-91.

12. Ehrlich HP, Wyler DJ. Fibroblast contraction of collagen lattices in vitro: Inhibition by chronic inflammatory cell mediators. J Cell Physiol 1983; 116(3):345-51.

13. Zamora JL. Chemical and microbiologic characteristics and toxicity of povidone-iodine solutions. Am J Surg 1986; 151(3):400-6.

14. Rabenberg VS, Ingersoll CD,Sandrey MA, Johnson MT. The bactericidal and cytotoxic effects of antimicrobial wound cleansers. J Athl Train 2002; 37(1):51-4.

15. Kaysinger KK, Nicholson NC, Ramp WK, Kellam JF. Toxic effects of wound irrigation solutions on cultured tibiae and osteoblasts. J Orthop Trauma 1995; 9(4):303-11. 